\title{
Pengaruh Supportive-Educative System terhadap Kualitas Hidup pada Pasien Gagal Jantung
}

\author{
The Effect of Supportive-Educative System on Quality of Life in Patients with Heart Failure \\ Ditha Astuti Purnamawati ${ }^{*}$, Fitri Arofiati ${ }^{2}$, Ambar Relawati $^{2}$ \\ ${ }^{1}$ Bagian Keperawatan Medikal Bedah, Sekolah Tinggi Ilmu Keperawatan Muhammadiyah Pontianak \\ ${ }^{2}$ Magister Keperawatan Program Pascasarjana Universitas Muhammadiyah Yogyakarta
}

DATA NASKAH:

Received: 21 Dec 2017

Reviewed: 22 Jan 2018

Revised: 05 Mar 2018

Accepted: 05 Apr 2018

*KORESPONDENSI:

ditha_astuti@yahoo.com

DOI:

10.18196/mm.180213

TIPE ARTIKEL:

Penelitian

\begin{abstract}
Abstrak: Gagal jantung adalah fase kronis yang menyebabkan kerusakan fungsional jantung akibat banyaknya gejala yang terjadi, sehingga akan berdampak pada kualitas hidup. Gagal jantung memerlukan penatalaksanaan yang tepat dan diharapkan dapat mencegah perburukan penyakit. Intervensi yang diberikan dapat berupa terapi farmakologi dan non farmakologi, diantaranya supportive-educative system. Sistem ini membantu pasien memperoleh informasi kesehatan, serta dalam pengambilan keputusan. Penelitian ini bertujuan untuk mengidentifikasi pengaruh supportiveeducative system terhadap kualitas hidup pasien gagal jantung. Penelitian ini merupakan penelitian kualitatif dengan metode quasi eksperiment. Rancangan penelitian yang adalah pre-posttest with control group. Sebanyak 34 pasien gagal jantung dipilih dengan teknik non probability sampling, dibagi menjadi dua kelompok secara acak, kelompok intervensi diberikan supportive-educative system, kelompok kontrol diberikan program discharge planning yang ada di ruangan, minggu pertama intervensi (pretest) untuk mendapatkan data kualitas hidup, minggu kedua dan ketiga observasi apakah responden melakukan kegiatan yang sudah diajarkan, minggu terakhir evaluasi (post-test) kualitas hidup setelah intervensi. Diuji menggunakan Wilcoxon test (data berdistribusi tidak normal) dan Paired Samples Test (data berdistribusi normal). Hasil uji beda menunjukkan kelompok intervensi lebih berpengaruh dibandingkan dengan kelompok kontrol dengan $\rho$ value sebesar 0,000. Terdapat pengaruh pemberian supportive-educative system terhadap kualitas hidup, kualitas hidup pada kelompok intervensi lebih baik daripada kelompok kontrol.
\end{abstract}

Kata kunci: Supportive-Educative System; Kualitas Hidup; Gagal Jantung

Abstract: Heart failure is a chronic phase that causes functional damage to the heart due to the many symptoms that occur, so that will affect the quality of life. Heart failure requires proper management and is expected to prevent worsening of the disease. The interventions given may include pharmacological and non pharmacological therapies, including supportiveeducative systems. This system helps patients obtain health information, as well as in decision-making. This study aims to identify the influence of supportive-educative system on the quality of life of patients with heart failure. This research is a qualitative research with quasi experiment method. The study design was pre-post test with control group. A total of 34 heart failure patients were selected with non-probability sampling technique, divided into two groups randomly, intervention group was given supportiveeducative system, control group was given discharge planning program in room, first week of intervention (pre-test) to get quality data live, second and third weeks of observation whether the respondent is doing the activity already taught, the last week of the post-test quality of life after the intervention. Tested using Wilcoxon test (abnormally distributed data) and Paired Samples Test (normal distributed 
data). Different test results showed the intervention group was more influential than the control group with $\rho$ value of 0.000. There is influence of giving supportive-educative system to quality of life, quality of life in intervention group is better than control group.

Key words: Supportive-Educative System; Quality of Life; Heart Failure

\section{PENDAHULUAN}

Gagal jantung merupakan salah satu penyakit tidak menular sebagai penyebab kematian nomor satu setiap tahunya. ${ }^{1}$ Gagal jantung adalah fase kronis yang dapat menyebabkan kerusakan fungsional jantung akibat banyaknya gejala. Banyaknya gejala yang dialami oleh pasien gagal jantung mempengaruhi kesehatanya. ${ }^{2}$

Prevalensi kasus gagal jantung di Indonesia pada tahun 2013 berdasarkan diagnosis dokter/gejala diperkirakan sekitar 530.068 orang. Penderita gagal jantung di Kalimantan Barat prevalensinya mencapai $0,2 \%$ berdasarkan diagnosis dokter dan gejala. ${ }^{1}$ Data rekam medik di Rumah Sakit Umum Daerah (RSUD) Dr. Soedarso Pontianak tahun 2016, jumlah pasien gagal jantung kongestif sebanyak 646 orang dan selama tiga bulan terakhir menempati posisi pertama dengan kasus terbanyak.

Perawat berperan penting dalam mencegah memburuknya penyakit akibat gagal janatung. pasien gagal jantung membutuhkan penatalaksanaan yang tepat, yaitu bersifat farmakologis dan non farmakologis. Perawat berkepentingan dalam penatalaksanaan non farmakologis, salah satu penatalaksanaan non farmakologis salah satunya berupa supportive educative system. dimana sistem ini membantu pasien dalam memperoleh informasi kesehatan, modifikasi prilaku serta pengambilan keputusan yang berhubungan dengan penyakitnya.

Menurut Etemadifar et al. (2014) 4 bahwa intervensi supportive-educative system merupakan intervensi yang efektif diberikan pada pasien gagal jantung karena intervensi ini bersifat sederhana, murah dan parktis diberikan, serta secara signifikan dapat meningkatkan kemampuan dan kepercayaan diri pasien gagal jantung

Yaghoubi et al. (2012), ${ }^{5}$ menyatakan gagal jantung dapat menyebabkan perawatan di rumah sakit berulang, kualitas hidup yang buruk, serta memendeknya harapan hidup. Hal ini sesuai dengan Yancy et al. (2013), ${ }^{6}$ gagal jantung secara signifikan menurunkan kualitas hidup pasien, yang berkaitan dengan fungsi fisik dan vitalitas, serta kualitas hidup yang tidak ditingkatkan setelah individu keluar dari rumah sakit adalah faktor utama individu dirawat kembali di RS dan kematian.

Penelitian ini bertujuan mengidentifikasi pengaruh supportive-educative system terhadap kualitas hidup pada pasien gagal jantung.

\section{BAHAN DAN CARA}

Variabel bebas pada penelitian ini adalah Supportive-educative system dan variabel terikat adalah kualitas hidup. Jenis penelitian ini adalah kualitatif dengan metode quasi eksperiment. Rancangan penelitian yang digunakan adalah pre-post test with control group.

Populasi dalam penelitian ini adalah seluruh pasien gagal jantung yang dirawat inap di RSUD Dr. Sudarso Pontianak pada bulan Januari 2018. Sampel dalam penelitian ini berjumlah 34 responden yaitu pasien penderita gagal jantung yang dirawat di ruang rawat inap yang telah memenuhi kriteria inklusi dan ekslusi penelitian.

Kriteria inklusi berupa pasien yang diagnosis gagal jantung dengan klasifikasi I-II menurut The New York Heart Association (NYHA), pasien yang bekerja, pengalaman pernah dirawat di rumah sakit dengan gagal jantung minimal satu kali. Kriteria ekslusi berupa penderita gagal jantung yang dengan komplikasi (stroke, atrial fibrilasi). ${ }^{7}$

Pengambilan sampel dengan menggunakan teknik non probably sampling dengan pendekatan consecutive sampling. Penelitian ini dilakukan selama empat minggu, minggu pertama dilakukan pretest data demografi responden dan data kualitas hidup sebelum dilakukan intervensi, kemudian dilakukan dilakukan intervensi. Kelompok Intervensi diberikan perlakuan berupa supportive-educative system dan kelompok kontrol menerima Discharge Planning yang ada di ruangan berupa berupa informasi jadwal kontrol dan obat-obatan yang diminum. Dilakukan observasi apakah responden melakukan kegiatan yang telah diajarkan, observasi dilakukan dengan telpon dan observasi dilakukan atu kali perminggu selama dua minggu pada kedua kelompok.

Data kualitas hidup pada kelompok intervensi menyatakan salah satunya berdistribusi tidak normal sehingga tetap menggunakan uji Wilcoxon, sedangkan kualitas hidup pada kelompok kontrol data berdistribusi normal sehingga menggunakan uji Paired Sampel T Test. 
HASIL

Karakteristik responden peneltian berdaarkan usia, jenis kelamin, pendidikan, pekerjaan dan pengalaman sakit dapat dilihat pada Tabel 1 .

Tabel 1. menunjukkan bahwa karakteristik usia responden terbanyak pada rentang kelompok usia 46-50 tahun yaitu kelompok intervensi dan kelompok kontrol masing-masing sebesar 15 responden $(88,2 \%)$. Jenis kelamin terbanyak adalah laki-laki pada kelompok intervensi 12 reponsen (70,6\%) dan pada kelompok kontrol 13 responden (76,5\%). Karakteristik tingkat pendidikan terbanya Sekolah Menengah Aatas (SMA) yaitu pada kelompok intervensi sebesar 11 responden $(64, \%)$ dan pada kelompok kontrol sebesar 12 responden (70,6\%).

Karakteristik pekerjaan terbanyak pada kelompok intervensi terbanyak adalah lainnya 7 responden (41,2\%) dan pada kelompok kontrol terbanyak adalah wiraswasta 6 responden (35,3\%). Data karakteristik pengalaman dirawat di rumah sakit pada kelompok intervensi dan kontrol terbanyak adalah dengan pengalaman sakit satu kali sebesar 31 responden $(91,17 \%)$ dan pengalaman sakit lebih dari satu kali 3 responden $(8,82 \%)$.

Tabel 1. Distribusi Responden Gagal Jantung Berdasarkan Usia, Jenis Kelamin, Pendidikan, Pekerjaan, dan pengalaman Sakit $(\mathrm{N}=34)$

\begin{tabular}{|c|c|c|c|c|}
\hline & \multicolumn{2}{|c|}{$\begin{array}{l}\text { Kelompok } \\
\text { Intervensi }\end{array}$} & \multicolumn{2}{|c|}{$\begin{array}{c}\text { Kelompok } \\
\text { Kontrol }\end{array}$} \\
\hline & $\mathrm{F}$ & $\%$ & $\mathrm{~F}$ & $\%$ \\
\hline \multicolumn{5}{|l|}{ Usia (Tahun) } \\
\hline $33-45$ & 2 & 11,8 & 2 & 11,8 \\
\hline $46-58$ & 15 & 88,2 & 15 & 88,2 \\
\hline \multicolumn{5}{|l|}{ Jenis kelamin } \\
\hline Laki-laki & 12 & 70,6 & 13 & 76,5 \\
\hline Perempuan & 5 & 29,4 & 4 & 23,5 \\
\hline \multicolumn{5}{|l|}{ Pendidikan } \\
\hline SD & 1 & 5,9 & & \\
\hline SMP & 2 & 11,8 & 2 & 11,8 \\
\hline SMA & 11 & 64,7 & 12 & 70,6 \\
\hline Perguruan Tinggi & 3 & 17,6 & 3 & 17,6 \\
\hline \multicolumn{5}{|l|}{ Pekerjaan } \\
\hline PNS & 4 & 23,5 & 2 & 11,8 \\
\hline Swasta & 1 & 5,9 & 3 & 17,6 \\
\hline Wiraswasta & 3 & 17,6 & 6 & 35,3 \\
\hline Petani & 2 & 11,8 & 5 & 29,4 \\
\hline Lainnya & 7 & 41,2 & 1 & 5,9 \\
\hline \multirow{2}{*}{\multicolumn{5}{|c|}{$\begin{array}{l}\text { Pengalaman dirawat di } \\
\text { RS dengan gagal jantung }\end{array}$}} \\
\hline & & & & \\
\hline 1 & 15 & 88,2 & 16 & 23,5 \\
\hline$\geq 1$ & 2 & 11,8 & 1 & 1,5 \\
\hline
\end{tabular}

Tabel 2. Perbedaan Kualitas Hidup antara sebelum (pre) dan sesudah (post) Pemberian Supportive-Educative System pada Kelompok Intervensi dan Kontrol $(\mathrm{N}=34)$

\begin{tabular}{lccc}
\hline $\begin{array}{l}\text { Kualitas } \\
\text { Hidup }\end{array}$ & Mean \pm SD & Min-Maks & P \\
\hline $\begin{array}{l}\text { Intervensi } \\
\text { Sebelum }\end{array}$ & $36,88 \pm 3,276$ & $31,00-44,00$ & $0,00^{*}$ \\
Sesudah & $30,94 \pm 2,221$ & $27,00-36,00$ & \\
Kontrol & & & \\
Sebelum & $37,18 \pm 3,127$ & $31,00-44,00$ & $0,00 *$ \\
Sesudah & $34,88 \pm 2,088$ & $31,00-39,00$ & \\
\hline${ }^{*} \mathrm{P}<0,05$ based on wilcoxon test & \\
${ }^{* *} \mathrm{P}<0,05$ based on Paired Samples Test &
\end{tabular}

Tabel 3. Perbedaan Selisih Kualitas Hidup antara sebelum dan sesudah Kualitas Hidup anatara Kelompok Intervensi dan Kontrol (N=34)

\begin{tabular}{lllc}
\hline \multicolumn{1}{c}{ Kualitas Hidup } & N & Mean & Sig \\
\hline Kelompok Intervensi & 17 & 24,47 & \multirow{2}{*}{0,00} \\
Kelompok Kontrol & 17 & 10,53 & \\
\hline
\end{tabular}

$\mathrm{P}<0,05$ based on Mann-Whitney Test

Berdasarkan Tabel 2. dapat diketahui bah-wa berdasarkan uji wilcoxon test didapatkan nilai $\rho$ value sebesar 0,046. Terlihat bahwa $\rho$-value $0,046<$ a $(0,05)$ menunjukkan hubungan bermakna secara signifikan kualitas hidup antara sebelum dan sesudah pemberian supportive-educative system pada kelompok intervensi.

Berdasarkan Tabel 2. diketahui berdasar-kan uji wilcoxon test didapatkan nilai $\rho$-value sebe-sar 0,00 . Nilai $\rho$-value $0,000<a(0,05)$ menunjuk-kan hubungan bermakna secara signifikan kualitas hidup antara sebelum dan sesudah pemberian supportive-educative system pada kelompok intervensi. Kelompok kontrol berdasarkan uji wilcoxon test didapatkan nilai $\rho$-value sebesar 0,00 . Nilai $\rho$ value $0,000<a(0,05)$ menunjukkan hubungan bermakna secara signifikan kualitas hidup antara sebelum dan sesudah pemberian supportive-edu-cative system pada kelompok kontrol.

Berdasarkan Tabel 3. menunjukan bahwa berdasarkan uji Mann-Whitney test, didapatkan nilai $\rho$-value sebesar 0,00. Nilai $\rho$-value $0,000<\alpha(0,05)$ menunjukan ada perbedaan pengaruh antara kelompok intervensi dan kelompok kontrol.

\section{DISKUS}

Berdasarkan hasil penelitian diketahui karakteristik responden berdasarkan usia untuk kelom- 
pok intervensi dan kontrol terbanyak pada kelompok usia 51-60 tahun sebesar 19 responden (55,88\%). Menurut Perhimpunan Dokter Spesialis kardiovaskular Indonesia (PERKI) tahun 2015, ${ }^{7}$ gagal jantung adalah masalah kesehatan yang terusmenerus dengan bertambahnya usia yang terjadi pada negara maju maupun negara berkembang. Riset Kesehatan Dasar (2013), ${ }^{8}$ menyatakan penderita gagal jantung banyak ditemukan pada kelompok umur 54-64 tahun. Karena gagal jantung merupakan proses berkeanjutan terhadap penurunan fungsi jantung baik secara struktur atau fungsional terutama pada ventrikel. Pemilihan responden dalam penelitian ini dibatasi antara umur 19-60 tahun. Lansia akan mengalami fungsi neorologis, serta sensori yang akan berpengaruh dalam penerimaan edukasi. Usia berpengaruh terhadap penerimaan informasi, dimana usia yang matang akan mempermudah penerimaan informasi yang yang diterima, hal ini sesuai dengan Potter \& Perry (2010), ${ }^{9}$ pada usia 40-65 tahun adalah waktu yang berpengaruh maksimal, menilai sendiri dan membimbing diri sendiri sehingga pada umur tersebut pasien memiliki efikasi diri yang baik, karena tahap ini disebut sebagai tahapan keberhasilan. Dengan demikian usia yang matang diharapkan akan berpengaruh dalam memudahkan pemberian supportive-educative pada responden, dalam hal ini adalah edukasi pada responden gagal jantung.

Berdasarkan hasil penelitian diketahui karakteristik responden berdasarkan jenis kelamin yaitu pada kelompok intervensi dan kelompok kontrol terbanyak adalah laki-laki yaitu 13 responden $(76,5 \%)$. Hal ini sesuai dengan penelitian Wahyuni \& Kurnia (2014), ${ }^{10}$ bahwa responden gagal jantung yang terbanyak adalah laki-laki yaitu sebesar 25 responden $(73,52 \%)$, sedangkan perempuan 9 responden (26,47\%). Hal ini selaras dengan Pudiarifanti et al. (2015), ${ }^{11}$ menyatakan kejadian gagal jantung lebih banyak lai-laki daripada perempuan. Hal ini berkaitan dengan hormon. Hormon estrogen pada perempuan diduga memiliki efek dalam mencegah kejadian gangguan kardiovaskular dengan menurunkan stres oksidatif.

Karakteristik tingkat pendidikan untuk kelompok intervensi dan kontrol terbanyak adalah SMA sebesar 23 responden (67,64\%), selanjutnya perguruan tinggi 6 responden (17,64\%), Sekolah Mengeah Pertama (SMP) sebesar 4 responden $(11,74 \%)$ dan Sekolah Dasar (SD) sebesar 1 responden (2,94\%). Hal ini selaras dengan penelitian Djaya \& Antono (2015), ${ }^{12}$ menyatakan bahwa tingkat pendidikan yang berada pada frekuensi tertinggi adalah subjek dengan pendidikan SMA atau sederajat (23,9\%).

Semakin tinggi pendidikan yang dimiliki maka semakin mudah menerima informasi yang diberikan. Karena seseorang yang memiliki tingkat pendidikan yang lebih tinggi akan mudah menyerap informasi dan memiliki pengetahuan yang lebih baik daripada seseorang yang tingkat pendidikanya lebih rendah. ${ }^{13}$ Pendidikan berpengaruh terhadap daya tangkap dan kemampuan seseorang memahami pengetahuan yang diperoleh dalam penerimaan informasi, dalam hal ini informasi mengenai gagal jantung, dimana responden yang berpendidikan lebih tinggi maka semakin mudah untuk menerima informasi. Tingkat pendidikan juga berpengaruh terhadap upaya seseorang dalam meperoleh sarana kesehatan, mencari pengobatan penyakit yang dideritanya dan mampu memilih serta memutuskan tindakan yang dijalaninya untuk mengatasi masalah kesehatanya.

Semua responden penelitian sudah bekerja, dengan hasil pada kelompok intervensi dan kontrol terbanyak adalah wiraswasta. Gagal jantung terjadi kelemahan fungsional jantung dengan gejala umum adalah kelelahan dan sesak, dengan melakukan aktivitas berlebihan akan semakin mengganggu fungsi jantung. Hal ini sesuai dengan Klabunde, (2015), ${ }^{14}$ aktivitas yang berat yang dilakukan terus menerus dan kurang beristirahat dapat meningkatkan kerja jantung dalam memompa darah keseluruh tubuh untuk memenuhi kebutuhan tubuh dalam melakukan aktivitas.

Karakteristk responden berdasarkan pengalaman dirawat di rumah sakit untuk karakteristik pengalaman sakit pada kelompok intervensi dan kontrol terbanyak adalah dengan pengalaman dirawat di rumah sakit satu kali yaitu sebesar 31 responden. Pengalaman sakit dibatasi oleh peneliti minimal satu kali dengan alasan, pengalaman sakit berhubungan dengan penerimaan pasien terhadap penyakitnya. Pengalaman sakit berpengaruh terhadap penerimaan sakit dan menerima edukasi, responden yang didiagnosis pertama kali atau tanpa pengalaman sakit akan mengalami penolakan terhadap sakitnya sehingga hal tersebut akan mempengaruhi responden dalam menerima edukasi.

Penelitian ini menunjukkan ada pengaruh kualitas hidup sebelum dan sesudah intervensi supportive-educative system pada kelompok intervensi. Hal ini selaras dengan hasil penelitian Chen (2018), ${ }^{15}$ bahwa program rehabilitasi jantung berbasis rumah, dapat meningkatkan kualitas hidup sebe- 
sar $37 \%$. Program yang diberikan berupa mengatur program rehabilitasi individual yang dilakukan di rumah, edukasi diet dan pengelolaan aktivitas sehari-hari selama periode tiga bulan. Peningkatan kualitas hidup ini terkait dengan peningkatan toleransi latihan, selain manfaat dari program rahabilitasi jantung itu sendiri dan program rehabilitasi rumah mudah diintegrasikan pada pasien. Hal ini sesuai dengan intervensi yang diberikan pada penelitian ini, dimana supportive-educative system berupa edukasi pengenalan penyakit gagal jantung, diet serta aktivitas fisik ketika dirumah.

Menurut Cowie et al. (2017), ${ }^{16}$ program perawatan optimal pada gagal jantung yang telah ditetapkan di 45 negara, dirancang untuk mengoptimalkan perawatan pasien ketika di rumah. Program ini membantu meningkatkan kesadaran akan perawatan gagal jantung dan menghasilkan data yang berguna mengenai praktik saat ini. Hasil awal menunjukkan bahwa program ini optimal dalam meningkatkan pengobatan farmakologis serta berpengaruh dalam meningkatkan kualitas hidup.

Pada kelompok kontrol menunjukkan ada perbedaan kualitas hidup antara sebelum dan sesudah pemberian supportive-educative. Hal ini mungkin dikarenakan kesadaran pasien gagal jantung yang tinggi pengobatan, karena kesadaran akan pentingnya pengobatan tidak hanya dipengaruhi dengan edukasi tetapi keinginan dari pasien untuk melakukan pengobatan dengan teratur. Hal ini sesuai dengan Chernomordik et al. (2017), ${ }^{17}$ pasien dengan gagal jantung yang dengan gejala simtomatik yang tetap, pengobatan teratur, pengobatan intravena dengan dosis rendah menunjukkan peningkatan kualitas hidup. Sehingga pasien yang disiplin dalam minum obat, teratur dalam kontrol rawat jalan berpengaruh dalam peningkatan kualitas hidup secara bertahap, tetapi tidak berpengaruh kelangsungan hidup jangka panjang.

Kelompok kontrol juga menunjukkan peningkatan kualitas hidup sebelum dan sesudah intervensi supportive-educative system tetapi nilainya tetap lebih rendah daripada kelompok intervensi. Hal ini juga diperkuat dari nilai selisih kualitas hidup pada kelompok intervensi dan kelompok kontrol yang menunjukkan bahwa ada perbedaan pengaruh antara kelompok intervensi dan kelompok kontrol, yaitu intervensi supportive-educative system pada kelompok intervensi lebih berpengaruh dibandingkan dengan kelompok kontrol.

Menurut Teichman \& Storrow (2015), ${ }^{18}$ pendidikan pasien harus dimulai lebih awal setelah masuk dan berlanjut melalui semua tingkat perawatan di rumah sakit. Ini memerlukan usaha dari beberapa anggota tim perawatan pasien, termasuk dokter dan perawat. Pendidikan seharusnya tidak terbatas pada pasien saja, anggota keluarga atau pengasuh harus disertakan bila memungkinkan.

Perawatan pasien tidak berakhir saat mereka dipulangkan dari rumah sakit karena pasien kemungkinan akan memerlukan bantuan tambahan dari apoteker, pekerja sosial dan keluarga mereka sendiri. Hal ini sesuai menurut penelitian Wang et al. (2017), ${ }^{19}$ penelitian ini memberikan bukti bahwa selain terapi standar, pasien dengan gagal jantung juga dapat memanfaatkan program promosi pendidikan khusus.

Program pendidikan khusus dapat berupa strategi pendidikan kesehatan yang dapat memberikan manfaat pada pasien dengan gagal jantung, yaitu program pendidikan manajemen mandiri efektif dalam meningkatkan kualitas hidup dan kepuasan pengobatan dan program asuhan keperawatan pendidikan yang mendukung dapat mengurangi kelelahan dan meningkatkan kualitas hidup.

Program perawatan diri dapat memperbaiki fungsi jantung dan memperkuat kemampuan dan efisiensi pasien untuk tampil perawatan diri dan program pengelolaan penyakit berbasis rumah dapat memperbaiki status psikologis, termasuk depresi dan kecemasan.

\section{SIMPULAN}

Penelitian ini menunjukkan terdapat pengaruh pemberian supportive-educative system terhadap kualitas hidup pasien gagal jantung, kualitas hidup pada kelompok intervensi lebih baik daripada kelompok kontrol.

\section{DAFTAR PUSTAKA}

1. Kementrerian Kesehatan Republik Indonesia. Infodatin: Situasi Kesehatan Jantung. Pusat Data dan Informasi Kementerian Kesehatan RI. 2014. p.1-8.

2. Ziaeian B, Fonarow GC. Epidemiology and Aetiology of Heart Failure. Nature Reviews. Cardiology, 2016; 13 (6): 368

3. Zamanzadeh V, Valizadeh L, Howard AF, Jamshidi F. A Supportive-Educational Intervention for Heart Failure Patients in Iran: The Effect on Self-Care Behaviours. Nurs Res Pract, 2013; 2013 (1): 1-7. 
4. Etemadifar S, Bahrami M, Shahriari M, Farsani AK. The Effectiveness of a Supportive Educative Group Intervention on Family Caregiver Burden of Patients with Heart Failure. Iran J Nurs Midwifery Res, 2014; 19 (3): 217-23.

5. Yaghoubi A, Tabrizi JS, Mirinazhad MM, Azami S, Naghavi-Behzad M, Ghojazadeh M. Quality of Life in Cardiovascular Patients in Iran and Factors Affecting it: A Systemic Review. J Cardiovasc Thorac Res, 2012; 4 (4): 95-101.

6. Yancy CW, Jessup M, Bozkurt B, Butler J, Casey DE Jr, Drazner MH, et al. 2013 ACCF/AHA Guideline for the Managenet of Heart Failure. Circulation, 2013; 128 (16): 1810-52.

7. Perhimpunan Dokter Spesialis kardiovaskular Indonesia (PERKI). Pedoman Tatalaksanan Gagal Jantung. Ed. ketiga. Jakarta: Centra Communications. 2015.

8. Riset Kesehatan Dasar (Riskesdas). Badan Penelitian dan Pengembangan Kesehatan Kementrian Kesehatan RI. Jakarta: Badan Litbangkes, Depkes RI. 2013.

9. Potter PA, Perry AG. Buku Ajar Fundamental Keperawatan: Konsep, Proses dan Praktik. Ed 4, Vol 2. Terjemahan. 2010.

10. Wahyuni A, Kurnia OS. Hubungan Self-Care dan Motivasi dengan Kualitas Hidup Pasien Gagal Jantung. Jurnal Keperawatan Padjajaran, 2014; 2 (2): 108-115 .

11. Pudiarifanti N, Pramantara ID, Ikawati Z. Faktorfaktor yang Mempengaruhi Kualitas Hidup Pasien Gagal Jantung Kronik. Jurnal Manajemen dan Pelayanan Farmasi, 2015; 5 (4): 259-266.

12. Djaya KH, Nasution SA, Antono D. Gambaran Lama Rawat dan Profil Pasien Gagal Jantung di Rumah Sakit Cipto Mangunkusumo. Indonesian Journal of Chest, 2015; 2 (4): 141-150.

13. Rini SS, Hairitama R. Kepatuhan Lansia Penderita Hipertensi dalam Pemenuhan Diet
Hipertensi. Sorot (Jurnal Ilmu-ilmu Sosial dan Ekonomi), 2014; 6 (1): 46-53.

14. Klabunde RE. Konsep Fisiologi Kardiovaskular. Ed. 2. Jakarta: EGC. 2015.

15. Chen YW, Wang CY, Lai YH, Liao YC, Wen YK, Chang ST et al. Home-Based Cardiac Rehabilitation Improves Quality of Life, Aerobic Capacity and Readmission Rates in Patients with Chronic Heart Failure. Medicine, 2018; 97 (4): e9629.

16. Cowie MR, Lopatin YM, Saldarriaga C, Fonseca C, Sim D, Magaña JA, et al. The Optimize Heart Failure Care Program: Initial Lessons from Global Implementation. Int J Cardiol, 2017; 236 (1): 340344.

17. Chernomordik F, Freimark D, Arad M, Shechter M, Matetzky S, Savir Y, et al. Quality of Life and Long-Term Mortality in Patients with Advanced Chronic Heart Failure Treated with Intermitten LowDose Intravenous Intropes in an Outpatient Setting. ESC Heart Fail, 2017; 4 (2):122-129.

18. Teichman SL, Maisel AS, Storrow AB. Challenges in Acute Heart Failure Clinical Management: Optimizing Care Despite Incomplete Evidence and Imperfect Drugs. Crit Pathw Cardiol, 2015; 14 (1): 12-24.

19. Wang Q, Dong L, Jian Z, Tang X. Effectiveness of a PRECEDE-Based Education Intervention on Quality of Life in Elderly Patients with Chronic Heart Failure. BMC Cardiovasc Disord, 2017; 17 (1): 262 . 